\title{
ブタにおける DNAフィンガープリント法の有用性
}

万年 英之・ 福田智一, 过荘一・後藤信男

神戸大学農学部家畜育種学研究室, 神戸市 657

\author{
Usefulness of DNA Fingerprinting for Swine \\ Hideyuki Mannen, Tomokazu Fukuda, Soichi Tsuji, \\ and Nobuo Goto
}

Laboratory of Animal Breeding, Faculty of Agriculture, Kobe University, Kobe 657, Japan

染色体上に散在するミニサテライト遺伝子座は, 反復 単位の繰り返し回数の違いによる多大な多型性を持って る。1985年に Jeffreys et al. (1985a) によって開発 された DNAフィンガープリント法は, この超可変ミ ニサテライト遺伝子座を検出する DNA多型分析法と いえる。検出されるバンド数は非常に多く, そのバンディ ングパターンは個体に特有である (Jeffreys et al., 1985b)。また子供のバンドは必ず両親のどちらかから 受け継ぐ (Jeffreys et al. ,1985c,1986)。この様な特 徵から, DNAフィンガープリント法は個体識別や親子 鑑別に有力な方法となることが知られている。最近では この他に，系統間の遺伝的距離を推定できること (Kuhnlein et al. ,1989), 生物集団の遺伝的構成の解 明に役立つことがわかつてきた (Wetton et al.,1987; Reeve et al.,1990; Gilbert et al. 1990)。家畜, 家 禽に対しても本法は, 個体識別や親子鑑別は勿論のこと, 将来的には選抜のマーカーとして利用できる可能性を秘 めている。そこで, 我々は M13ファージ DNAの反復 配列をプローブとして用いる場合, 本法が豚でも上述の ような核 DNAの分析に適しているか否かを調べるた め, 制限酵素の種類, ハイブリダイゼーションなど最適 条件を模索した。また，こうして得られたフィンガープ リント像について, 親子鑑別と豚品種間の類似性など分 析した結果を報告する。

\section{材料と方法}

豚は梅山豚, 金華豚, ランドレース種の 3 品種, 梅山 豚と金華豚の F1, 日本コッワルド K. K. 産のコッワル ド PS（ランドレース種と大ヨークシャー種との合成豚）
とコッワルド28（大ヨークシャー種, ハンプシャー種, デュロック種, ピエトレン種の合成豚）のＦ１を用い た。

DNAの精製: DNAは血液か精子のいずれかから抽出, 精製して用いた。血液からの DNAの 精製は白血球 から行った。 $1 \mathrm{mg} / \mathrm{ml}$ EDTA 存在下で血液を採血 L, 3000rpm, 10分間の条件で遠心分離した後, 白血球 層を分取した。10倍量以上の $0.2 \% \mathrm{NaCl}$ に良く混合 L, 3000rpm， 5 分間の遠心分離で核を集めた。少量の 生理食塩水に核を良く混合し, ザルコシル溶液 $[0.5 \%$ N-lauroylsarcosine sodium salt, $10 \mathrm{mM}$ Tris-

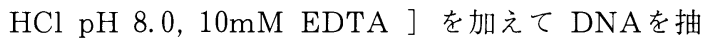
出した。次いで, $100 \mu \mathrm{g} / \mathrm{ml}$ の Proteinase $\mathrm{K}$ を加 え, $37^{\circ} \mathrm{C}$ で 1 晚インキュベートした。この溶液に TEphenolを加え, ゆっくりと10分間混和した後, $3000 \mathrm{rpm}$ 10分間遠心分離し，水層を分取した。同様の操作を phenol • chloroform, chloroform で行った。Ethyl ether を 加えて phenol を除き, 10分間の 1 量の sodium acetate (pH 5.2)，2倍量の ethanol を加えて DNAを沈殿させ た $70 \%$ ethanol で DNAを洗浄後, ethanol を完全に 除き，TE に溶かし，サンプルとした。

精子からの DNA精製は次の操作に従った。採取した精液 に対し10倍量以上の生理食塩水を加え, 良く混合し, $3000 \mathrm{rpm} 10$ 分間遠心分離した。この操作を計 3 回行っ た。集めた精子と当量の生理食塩水を加え, 良く混合し た後, $4 \mathrm{M}$ guanidine tiocyanate, $25 \mathrm{mM}$ sodium acetate, $0.84 \beta$-mercapto ethanol を加え, $37^{\circ} \mathrm{C}$ で 1 晚インキュベートした。0.6倍量の 2 -propanol を加 えて DNAを沈殿させ，70\% ethanol で良く洗浄した 後にザルコシル溶液に溶かした。以下の操作は血液から 
のDNA精製と同様に行った。

DNAの制限酵素消化と電気泳動：用いた制限酵素は， Hae III, Msp I, Eco RI, Bam HI, Hind III，およ びPst Iの 6 種類である。制限酵素で消化した DNA $10 \mu \mathrm{g}$ を $1.2 \%$ アガロースゲルで $2 \mathrm{~V} / \mathrm{cm}$ の条件で電気 泳動した。以下の操作は基本的にVassart et al. （1987）の方法に従った。すなわち, 電気泳動が終了し
たゲルは $0.5 \mathrm{M} \mathrm{NaOH}, 1.5 \mathrm{M} \mathrm{NaCl} に 1$ 時間, $1 \mathrm{M}$ ammonium acetate, $0.03 \mathrm{M} \mathrm{NaOH} に 1$ 時間浸した 後, サザントランスファーにより，ニトロセルロース膜 (Schieicher \& Schuell) に移行した。

プローブの作成とハイブリダイゼーション：プローブは M13ファージの反復配列を用いた。 $5 \mu \mathrm{g}$ の ssM13mp $18 \mathrm{DNA} 2 \mathrm{MBq}$ の $\left[\alpha-{ }^{32} \mathrm{P}\right] \mathrm{dCTP}$ でオリゴ・

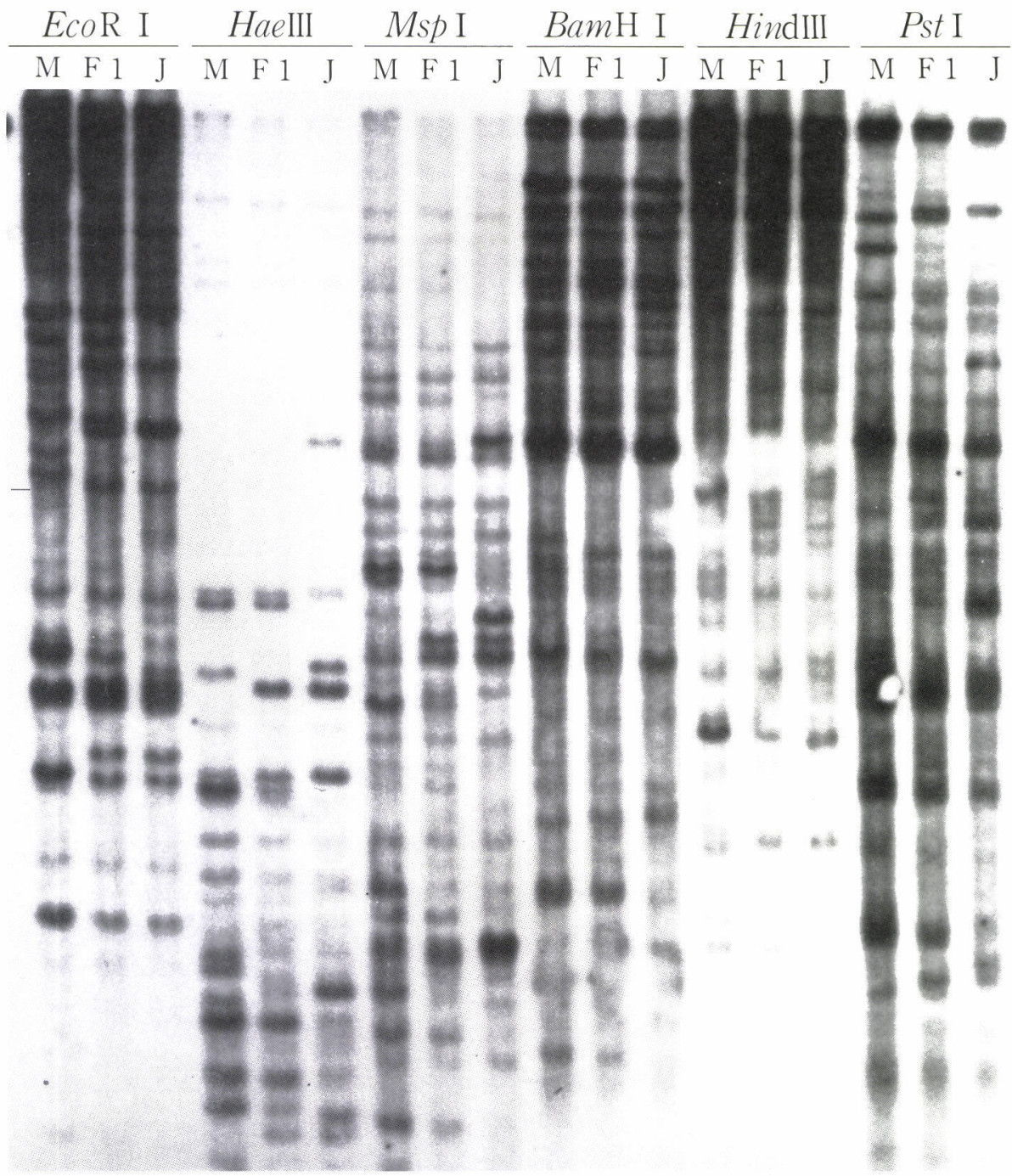

Fig.1. Parentage test using DNA fingerprints digested with respective restriction enzymes (Eco RI, Hae III, Msp I, Bam HI, Hind III, Pst I). M:Meshan Pig; J:Jinhua Pig; Fl:Fl hybrid $\left(\mathrm{M}\right.$ 우 $\left.\times \mathrm{J} \sigma^{7}\right)$. 
プライマー法を用いて標識し，プローブとした。ハイブ リダイゼーションは, $40 \%$ formamide, $6 \times \operatorname{SSC}(1 \times$ SSC $0.15 \mathrm{M} \mathrm{NaCl}, 15 \mathrm{mM}$ sodium citrate), $5 \mathrm{mM}$ EDTA, 0.25\% skim milk の溶液中で 1 晚行った。 メンブランは $4 \times \mathrm{SSC}, 0.1 \% \mathrm{SDS}, 55^{\circ} \mathrm{C}$ の溶液中で 30 分間, 2 回洗浄し, $2 \times \mathrm{SSC}, 0.1 \% \mathrm{SDS}, 55^{\circ} \mathrm{C}$ の溶 液中で30分間洗浄した後に，オートラジオグラムを得た。 DNAフィンガープリントの評価：2 個体間におけるバ ンドパターンの比較は, 次式によった（Wetton et al. ,1987)。

$$
\mathrm{D}=2 \mathrm{~N}_{\mathrm{AB}} /\left(\mathrm{N}_{\mathrm{A}}+\mathrm{N}_{\mathrm{B}}\right)
$$

$\mathrm{N}_{\mathrm{AB}}$ は個体 $\mathrm{A}$ と $\mathrm{B}$ に共通のバンド数, $\mathrm{N}_{\mathrm{A}}, \mathrm{N}_{\mathrm{B}}$ は個体 $\mathrm{A}$, $\mathrm{B}$ それぞれのバンド数，Dは遺伝的類似性の指数を示す。

\section{結果}

図 1 は梅山豚の雌, 金華豚の雄, およびその子供の親 子鑑別を行ったものである。Mは梅山豚，Jは金華豚， F1はその子供を示す。各豚の核 DNA 6 種の制限酵 素 (Eco RI, Hae III, Msp I, Bam HI, Hind III, Pst I) でそれぞれ消化し，フィンガープリント像を得 た。いずれの制限酵素を用いても子供のバンドは必ず両 親のどちらかから由来しており，親子鑑別が可能である ことがわかる。DNA断片の大きさが $1 \mathrm{~kb} ら 20 \mathrm{~kb}$ の 範囲でのバンド数は制限酵素によって異なり，Eco RI: $24.7 \pm 1.3$, Hae III: 13.7士3.1, MspI: $21.7 \pm 2.1$, Bam HI: $18.3 \pm 2.1$, Hind III: $19.7 \pm 0.5$, Pst I: $15.7 \pm 0.5$ (Mean $\pm \mathrm{SD}$ ) であった。全体像のパターン は，用いる制限酵素によって特徽的であった。大別して， 極端に高分子領域にバンドが集中しているもの (Hind III)，比較的高分子領域にバンドが散在している もの (Eco RI, Bam HI)，全体的にバンドが散在し ているもの (Pst I, Msp I)，大部分のバンドが低分子 領域に存在しているもの（Hae III）であった。

図 2 は, 制限酵素 $M s p$ Iを用いた豚 3 品種, 合成豚 のF1の DNAフィンガープリントである。どの個体も $1 \mathrm{~kb} ら 20 \mathrm{~kb}$ 範囲で，20～25本のバンドが観察された。 品種内, 品種間のどの個体においても個体特有のバンディ ングパターンが観察された。

品種内, 品種間で遺伝的類似性を調べた結果が, 表 1 に示してある。品種内ではどの品種も D值が高い。それ に対し, 品種間のD値は品種内の約半分である。組み合 わせのうち，ランドレース種と合成豚のF1が他の組み 合わせ $(\mathrm{D}=0.28)$ と比較して高い值を示した $(\mathrm{D}=0.38)$ 。

\section{考察}

本報告では，M13ファージ DNAの反復配列をプロー ブとして用い, 豚核 DNAのフィンガープリント分析 を行った。M13プローブは大腸菌から高等生物にいたる まで，多種にわたるミニサテライト DNAとハイブリ ダイズし，フィンガープリントが得られることが報告さ れている (Vassart et al.,1987; Rogstad et al., 1988; Ryskov et al.,1988; Nybom \& Schaal,1990; 万年 5,1990$)$ 。

6 種の制限酵素を用いたそれぞれのフィンガープリン 卜像の全体のパターンは，それぞれの制限酵素によって 特徵的であった（図 1 )。制限酵素の認識部位が，検出 されるミニサテライト領域に存在せず，その他の領域に ランダムに存在するのであれば，4塩基認識の制限酵素 間では同じような全体像が得られるはずである。6 塩基 認識の制限酵素間でも同じである。6 塩基認識の制限酵 素は, Pst I, Eco RI, Bam HI, Hind III である。 Eco RIとBam HIでは全体像がよく似ているのに対し, Hind IIIではそれよりも高分子領域にバンドが集中して おり，Pst Iでは全域にバンドが分散している。4 塩基 認識の制限酵素は, Hae III $M s p$ Iである。Msp Iで は全域にバンドが分散しているが，Hae IIIでは高分子 領域にはバンドはほとんど存在していない。これらの理 由は明確ではないが，1）Hind IIIでは，その認識配列 がミニサテライト領域の前後に存在している頻度が低い ため, 1 つのバンドが複数のミニサテライト領域を含ん でいる，2）Pst Iや Hae IIIでは，プローブに対する いくつかのミニサテライト領域の反復単位中に, これら の制限酵素の認識配列が存在するために検出される領域 数が減っている，などの理由が考えられる。

いずれの制限酵素を用いても親子鑑別が可能であった が（図 1)，豚の分析に適した制限酵素は 1) バンド数 が多い，2）バンドやバックグランドがスメアになって いない，3）バンドが散在しているため分析が容易とい う点から， Msp I が適していると思われる。

豚の 3 品種と合成豚のF1に対する分析では, 個体に 特有のバンディングパターンが観察され，個体識別が可 能であることが示唆された（図 2 )。また，品種内と品 種間で遺伝的類似性を，前述の式に従って求めたところ (表 1)，品種内では高い $\mathrm{D}$ 值が観察された $(0.45 \sim 0.61)$ 。 これはどの品種および合成豚の F1も少集団から得られ ているので，個体間の血縁が高まっているものと思われ る。特に梅山豚，金華豚のコロニー（神戸大）は，数頭 の種畜から構成されたので特にD值が高くなっているも のと思われる。品種間の $\mathrm{D}$ 值は, 品種内の值と比較して 


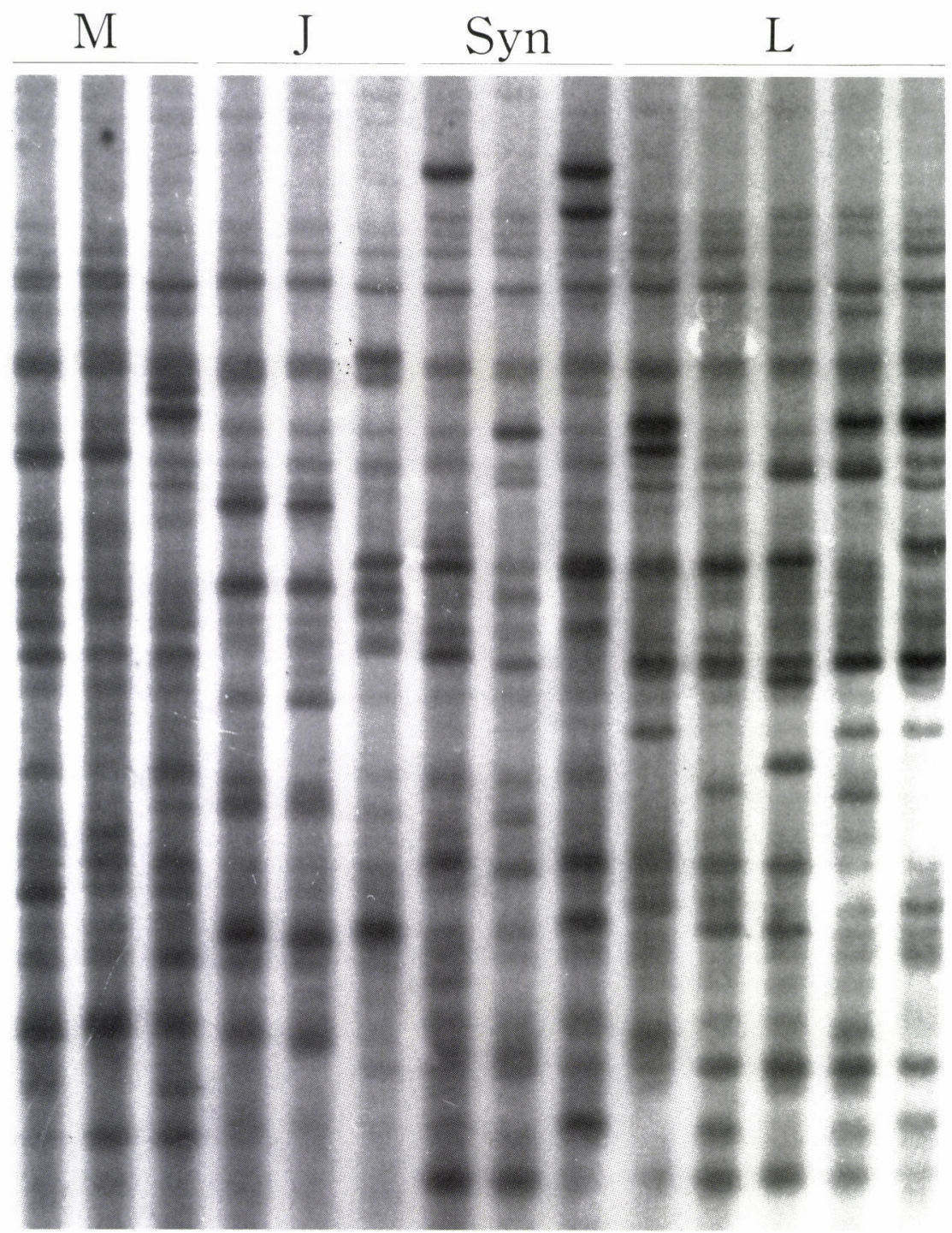

Fig.2. DNA fingerprints of three breeds and synthetic swine M:Meishan Pig; J:Jinhua Pig; L:Landrace; Syn: F1 hybrid (Cotswold PS $+\times$ Cotswold $28 \sigma^{7}$ ). 
Table 1 Similarity* matrix among 3 breeds and synthetic swine (Mean $\pm \mathrm{SD}$ )

\begin{tabular}{ccccc}
\hline & M & J & L & Syn \\
\hline M & $0.57 \pm 0.16$ & $0.29 \pm 0.05$ & $0.24 \pm 0.09$ & $0.30 \pm 0.05$ \\
J & & $0.61 \pm 0.22$ & $0.28 \pm 0.06$ & $0.28 \pm 0.04$ \\
L & & & $0.45 \pm 0.09$ & $0.38 \pm 0.08$ \\
Syn & & & & $0.53 \pm 0.18$
\end{tabular}

Valus on the diagonal are within breed and off diagonal between breeds.

*: See text

M: Meishan Pig J: Jinhua Pig L: Landrace

Syn: F1 hybrid (Cotswold PS 우 $\times$ Cotswold 28 ठ)

約半分であった $(0.24 \sim 0.38)$ 。合成豚のF1とランドレー ス種のフィンガープリント像の組み合わせでは, 他の組 み合わせのものと比較して高いD值を示した（表 1 ）。 これは合成豚にランドレース種を用いているために，他 の組み合わせより遺伝的に近縁になっているためであろ う。これらの結果から DNAフィンガープリント法に よる分析は, 遺伝的類似性を直接反映しているものと言 える。

\section{要 約}

M13 ファージの反復配列をプローブとして用い，豚 核 DNAのフィンガープリントを得る場合，制限酵素 としては Msp Iが最も適していた。梅山豚，金華豚， そのF1の親子鑑別では, F1のバンドは必ず親のどちら かに由来しており親子鑑別が可能であった。豚 3 品種, 合成豚を用いて検討したところ，各個体毎に特有のバン ディングパターンが得られ，個体識別が可能であること が示唆された。これらから遺伝的類似性を比較した結果, 品種間よりも品種内で遺伝的に近く, フィンガープリン 卜像は遺伝的背景を反映していることが示唆された。

\section{謝 辞}

本研究の遂行に当たり，貴重な試料を提供してくださっ た丸紅飼料株式会社技術センターの菱山和洋氏に媣く感 謝します。

\section{文献}

Gilbert, D. A., N. Lehman, S. J. O’Brien \& R. K. Wayne, 1990. Genetic fingerprinting reflects population differentiation in the California Channel Island fox. Nature, 344: 764-766.

Jeffreys, A.J., V.Wilson \& S. L. Thein, 1985a. Hypervariable 'minisatellite' regions in human DNA. Nature, 314: 67-73.

Jeffreys, A. J., V. Wilson \& S. L. Thein, 1985b. In dividual-specific 'fingerprints' of human DNA. Nature, 316: 76-79.

Jeffreys, A.J., J.F.Y.Brookfield \& R. Semmeonoff, 1985c. Positive identification of an immigration test-case using human DNA fingerprinting. Nature, 317: 818-819.

Jeffreys, A.J., V.Wilson, S.L.Thein, D.J. Weatherall \& B.A.J.Ponder, 1986. DNA "fingerprints" and segregation analysis of multiple markers in human pedigrees. Am. J. Genet. , 39: 11-24.

Kuhnlein, U. Y., Y. Dawe, D. Zadworny \& J.S. Gavora, 1989. DNA fingerprinting: a tool for determing genetic distances between strains of poultry. Theor, Appl.Genet., 77: 669-672.

万年英之, 辻 荘一, 後藤信男, 1990. M13ファージを 用いたニワトリ核 DNAのフィンガープリント. 日畜会報, 61：1057-1062. 
Nybom, H. \& B. A. Schaal, 1990. DNA "fingerprints" applied to paternity analysis on apples (malus X domestica). Theor. Appl. Genet. , 79: 763-768.

Reeve, H. K., D. F. Westneat, W. A. Noon, P. W. Sherman \& C. F. Aquadro, 1990. DNA fingerprinting reveals high level of inbreeding in colonies of the eusocial naked mole-rat. Proc. Natl. Acad. Sci. USA, 87: 2496-2500.

Rogstad, S.H., J.C.Patton II \& B. A. Schaal, 1988. M13 repeat probe detects DNA minisatellites-like sequence in gymnosperms and angiosperms. Proc. Natl. Acad. Sci. USA, 86: $9176-9178$.
Ryskov, A.P., A. G. Jincharadze, M. I. Prosnyal, P. L. Ivanov \& S. A. Limborslaya, 1988. M13 Phage DNA as a universal marker for DNA fingerprinting of animals, plants and microorganisms. FEBS, 233: 388-392.

Vassart, G., M. Georges, R. Monsieur, H. Brocas, A.S. Lequarre \& D. Christophe, 1987. A sequence in M13 phage detects hypervariable minisatellites in human and animal DNA. Science, 235: 683-684.

Wetton, J.H., R. E. Caeter, D.T.Parkin \& D. Walters, 1987. Demographic study of a wild house sparrow population by DNA fingerprinting. Nature, 327: 147-149.

\title{
Usefulness of DNA Fingerprinting for Swine
}

\author{
Hideyuki Mannen,Tomokazu Fukuda, Soichi Tsuji, \\ and Nobuo Goto
}

Laboratory of Animal Breeding, Faculty of Agriculture, Kobe University, Kobe 657, Japan

For obtaining clear DNA fingerprint and detecting variation with the bacteriophage M13 probe in swine, Msp I was suitable enzyme in the several restriction enzymes examined. Parentage test was carried out with fingerprints of Meishan Pig, Jinhua Pig and their F1 offspring. All bands of F1 were always originated from either parent. DNA fingerprinting analysis of their breeds (Meishan Pig, Junhua Pig and Landrace) and synthetic swine showed that their banding pattern is specific to each individual. Comparison with these banding patterns suggested the pattern is more similar within breeds than between breeds. Thus, DNA fingerprinting is useful not only for identifying the individual and parent-offspring but also for classifying the breeds of swine. 